\title{
OPTIMIZING THE SEEDING RATE IN SUBSOILING FOR DRYLAND WHEAT (TRITICUM AESTIVUM L.): A KEY TO IMPROVING WATER USE EFFICIENCY AND NITROGEN USE EFFICIENCY IN THE LOESS PLATEAU OF CHINA
}

\author{
LIN, W. - LI, H. - REN, A. - SUN, M. ${ }^{*}$-GAO, Z. \\ College of Agronomy, Shanxi Agricultural University, Taigu, Shanxi 030801, China \\ *Corresponding author \\ e-mail:sm_sunmin@126.com,gaosxau@163.com
}

(Received $16^{\text {th }}$ Nov 2019; accepted $12^{\text {th }}$ Feb 2020)

\begin{abstract}
The effects of seeding rate and tillage on water use and nitrogen use efficiencies were studied based on a field experiment carried out from 2012 to 2016. The results showed that subsoiling significantly increased the soil water storage before sowing in all years. The water consumption (ET) during the four years was, on average, 461 and $301 \mathrm{~mm}$ for subsoiling (SS) and CK, respectively. The average yield of SS was $4821 \mathrm{~kg} / \mathrm{ha}$, which was $944 \mathrm{~kg} / \mathrm{ha}$ higher than that of CK. The average yield was highest at the mid-seeding rate for both SS and CK, with values of 5115 and $4394 \mathrm{~kg} / \mathrm{ha}$, respectively. Since the nitrogen fertilizer application rate was the same, a higher yield indicates a higher nitrogen use efficiency (NUE). Contribution analysis showed that the higher seeding rate led to a lower contribution of nitrogen uptake efficiency (UPE) and a higher contribution of NHIp to NUEp. In summary, subsoiling during summer fallow period increased the soil water retention and improved the wheat yield and WUE. It also increased nitrogen uptake and NUEp. The mid-seeding rate (approximately $90 \mathrm{~kg} / \mathrm{ha}$ ) under subsoiling is optimal for improving water use efficiency (WUE) and NUE in the Loess Plateau.
\end{abstract}

Keywords: dryland farming, contribution analysis, water use efficiency, soil tillage, nitrogen fertilizer

\section{Introduction}

In dryland farming areas, water is a limiting factor for crop production. In most regions of the Loess Plateau, the groundwater is deep, and no irrigation water can be obtained; hence, the crops are rain-fed (Kang et al., 2002). Winter wheat (Triticum aestivum $\mathrm{L}$.) is one of the main crops in this area. With a continental monsoon climate, the rainfall in the Loess Plateau is low and mainly falls in July, August, and September (Wang et al., 2011). However, this period occurs during the fallow period of winter wheat, which grows from early October to the following June. The rainfall during the wheat growth season is insufficient for optimal crop growth; approximately 30-40\% of the required water comes from the soil water stored before sowing (Zhang et al., 2013).

A higher temperature in the fallow period makes it easier for the soil water to be lost by evaporation (Han et al., 2015). To conserve more water in the soil for wheat growth, the precipitation storage efficiency (PSE) should be increased during that period. In agronomy, there are two main types of practices to increase the PSE: reduce soil evaporation and increase soil infiltration (Nielsen and Vigil, 2010). To reduce evaporation, soil surface mulching techniques can be applied, among which plastic mulching and straw mulching are widely used (Zhang et al., 2013). Research shows that plastic film increases soil moisture in topsoil by $12.9 \%$ (Ma et al., 2018). Soil infiltration is related to soil physical properties. Tillage modifies the soil physical properties, such as the soil bulk density, which will further influence soil infiltration (Gómez et al., 1999). Subsoiling is a tillage practice that decreases the soil bulk density 
and increases the amount of water infiltration. Previous studies have shown that subsoiling increases the water storage in drylands (Bhatt and Khera, 2006). In the Loess Plateau, soil water storage was increased by $76 \mathrm{~mm}$ in the $0-200 \mathrm{~cm}$ layer under subsoiling during the summer fallow period (Liao et al., 2002).

Nutrients represent another limiting factor in dryland farming. The nitrogen fertilizer use efficiency (NUE) is low in dryland farming areas (Zhu and Chen, 2002). Low soil moisture decreases nutrient availability sand impacts the uptake of nutrients by crops; thus, the NUE in the dryland farming area is low (Guntiñas et al., 2012). The improved soil water conditions under subsoiling may improve the nutrient conditions in the field by making nutrients such as nitrogen more available for crops (Zhu et al., 2018), which providing crops with a better growth environment and increases productivity (Basso et al., 2010).

The seeding rate influences the wheat population, which further influences the use of soil water and nutrients and finally influences wheat growth and yield formation (Kühling et al., 2017). Wheat yield increases with the increase in seeding rate under the low sowing rate and peaks at a certain threshold value, after which it might not increase and may even cause a decrease in grain yield (Bhatta et al., 2017). Whether the optimum seeding rate changes due to the application of subsoiling still need to be addressed.

The process of nitrogen use by winter wheat can be simplified into two stages (Sadras and Lawson, 2013). In the first stage, plants uptake $\mathrm{N}$ from the soil and store it in leaves and stems. In this process, the $\mathrm{N}$ availability impacts its uptake. In winter, wheat $\mathrm{N}$ uptake represents 75 to $90 \%$ of the total $\mathrm{N}$ in the plant at harvest (Delogu et al., 1998). In the second stage, $\mathrm{N}$ is translocated to grains during grain filling. Many previous studies have focused on the uptake and translocation of nitrogen. However, few studies have focused on how nitrogen absorption and transportation respond to subsoiling and seeding rates. To clarify this issue, a field experiment on subsoiling in the fallow period and different wheat seeding rates was carried out from 2012 to 2016 in the Loess Plateau of China.

\section{Materials and methods}

\section{Site description}

The study was conducted at the experimental station of Shanxi Agricultural University in Wenxi County, Shanxi Province, China $\left(35^{\circ} 20^{\prime} \mathrm{N}, 111^{\circ} 17^{\prime} \mathrm{E}\right.$, and elevation $639 \mathrm{~m}$ ), from 2012 to 2016 . The experimental site is a dryland area, with an average precipitation of $484 \mathrm{~mm}, 60-70 \%$ of which is concentrated during the fallow period of winter wheat. To improve the water use, all the experiment was carried out based on plastic film mulch. The basic nutrient properties of the soil in the experimental field in 2012 are shown in Table 1.

\section{Crop management}

After harvesting the previous wheat, wheat stubble with a height of $20-30 \mathrm{~cm}$ was left in the field until mid-July. Subsoiling was performed during the fallow period by a subsoiler (IS-200, Xiuyuan Agricultural Machinery Co.) to a depth of 30-40 cm in midJuly, followed by rotary tillage to crumble large soil lumps and to level the field around 20 August. The winter wheat variety used in this study was 'Yunhan20410', which was 
the recommended variety by the local agricultural extension department due to its drought stress resistance ability. The suggested sowing rate of Yunhan20410 is $90 \mathrm{~kg} / \mathrm{ha}$, if the sowing date is delayed due to climate condition, the sowing rate may be increased to $105 \mathrm{~kg} / \mathrm{ha}$. During the four experimental years, wheat was sown in late September or early October and harvested around 20 June. Before sowing, chemical fertilizer was applied at a rate of $150 \mathrm{~kg} \mathrm{ha}^{-1}$ nitrogen, $150 \mathrm{~kg} \mathrm{ha}^{-1} \mathrm{P}_{2} \mathrm{O}_{5}$ and $150 \mathrm{~kg} \mathrm{ha}^{-1}$ $\mathrm{K}_{2} \mathrm{O}$. Since no irrigation was applied during the experiment, no fertilizer was applied during the entire growth period. Weeds and pests were controlled by herbicides as needed.

Table 1. Main soil chemical properties before sowing in 2012

\begin{tabular}{c|c}
\hline Soil nutrients & Content \\
\hline Organic matter $\left(\mathrm{g} \mathrm{kg}^{-1}\right)$ & 11.88 \\
Total nitrogen $\left(\mathrm{g} \mathrm{kg}^{-1}\right)$ & 0.61 \\
Alkali-hydrolysis nitrogen $\left(\mathrm{mg} \mathrm{kg}^{-1}\right)$ & 38.62 \\
Available phosphorous $\left(\mathrm{mg} \mathrm{kg}^{-1}\right)$ & 14.61 \\
Available potassium $\left(\mathrm{mg} \mathrm{kg}^{-1}\right)$ & 238.16 \\
$\mathrm{pH}$ & 8.08 \\
\hline
\end{tabular}

\section{Experimental design}

The experiment was conducted with a two-factor split plot design, taking the tillage practice as a main factor and the planting density as a sub-plot factor. The two tillage practices were the subsoiling (SS) and the no tillage (NT) condition, which was the control. Under each tillage method, three planting densities, low (L, 60-75 kg seed ha-1, $<190 \times 10^{6}$ plants ha $\left.{ }^{-1}\right)$, mid $\left(\mathrm{M}, 90-105 \mathrm{~kg}\right.$ seed ha ${ }^{-1}, 190-260 \times 10^{6}$ plants ha $\left.{ }^{-1}\right)$, and high $\left(\mathrm{H}, 112.5-120 \mathrm{~kg}\right.$ seed ha ${ }^{-1},>320 \times 10^{6}$ plants $^{-1}$ ) were used in the experiment. Seeds were sown at rates of $67.5,90$ and $112.5 \mathrm{~kg} \mathrm{ha}^{-1}$, after which a 3-leaf stage planting density of 190,260 and 320 plants $\mathrm{m}^{-2}$ was attained by thinning. Each treatment was repeated three times with a total of 18 plots. Each sub-plot $\left(150 \mathrm{~m}^{2}\right)$ was $50 \mathrm{~m}$ long and $3 \mathrm{~m}$ wide with a line spacing of $30 \mathrm{~cm}$.

\section{Measurements}

\section{Soil water storage}

The soil was sampled every $20 \mathrm{~cm}$ to a depth of $300 \mathrm{~cm}$ and soil water content was determined gravimetrically before planting and after harvest. The precipitation data were obtained from the meteorological station at the experimental site (Table 2).

Table 2. Precipitation and mean temperature in fallow period and in growth stage during the experiment $(\mathrm{mm})$

\begin{tabular}{c|c|c|c|c|c}
\hline & Stage & $\mathbf{2 0 1 2 - 2 0 1 3}$ & $\mathbf{2 0 1 3 - 2 0 1 4}$ & $\mathbf{2 0 1 4 - 2 0 1 5}$ & $\mathbf{2 0 1 5 - 2 0 1 6}$ \\
\hline $\begin{array}{c}\text { Precipitation } \\
(\mathrm{mm})\end{array}$ & Fallow period & 188 & 288 & 284 & 95 \\
\hline Temperature & Growth stage & 167 & 202 & 190 & 292 \\
$\left({ }^{\circ} \mathrm{C}\right)$ & Fallow period & 24.9 & 26.7 & 24.8 & 24.7 \\
\hline
\end{tabular}


As the plots were on a flat experimental field with ridges around them, the plots were not influenced by surface runoff. Moreover, the influence of groundwater can be ignored because the groundwater level is low in this region. The evapotranspiration (ET) and water use efficiency (WUE) were obtained through Equations 1 and 2 (Li et al., 2013):

$$
\begin{gathered}
E T=P+\Delta W \\
W U E=\frac{Y}{E T}
\end{gathered}
$$

where $\Delta \mathrm{W}$ is the soil water depletion during the wheat growing stage, and $\mathrm{Y}$ is the grain yield.

\section{Nitrogen content}

Plant nitrogen content was determined using the semi-micro Kjeldahl method, and wheat protein content was obtained by multiplying the $\mathrm{N}$ content (\%) by 5.7 (Halvorson et al., 2004).

\section{Grain yield}

At maturity, plants from three $1 \mathrm{~m}^{2}$ size sample plots were harvested from each plot to determine the grain yield $\left(\mathrm{kg} \mathrm{ha}^{-1}\right)$.

\section{Contribution analysis}

In this research, because soil available nitrogen was not measured, we focused on the use efficiency of nitrogen from fertilizer and then the NUE, which is defined as the ratio of the grain yield (Y) and nitrogen fertilizer application rate (Nf) (Moll et al., 1982). The nitrogen fertilizer use efficiency for protein (NUEp) is defined as the ratio of the grain nitrogen $(\mathrm{Ng})$ and nitrogen fertilizer application rate. The NUE can be partitioned into the components of UTE (the ability of the plant to convert the absorbed $\mathrm{N}$ into harvested grain yield, Y/Nt) and UPE (nitrogen uptake efficiency, Nt/Nf). NUEp can be separated into the components of UPE and NHI (nitrogen harvest index, $\mathrm{Ng} / \mathrm{Nt}$ ) ( $\mathrm{Van}$ Sanford and Mackown, 1986). Equations 3 and 4 express the relationship between these indexes.

$$
\begin{aligned}
& N U E=U P E \times U T E \\
& N U E p=U T E \times N H I
\end{aligned}
$$

To analyse the contribution of the components to NUE, we calculated the natural log of the three components using Equation 5:

$$
\ln N U E=\ln U P E+\ln U T E
$$

Then, both individual components of NUE can be regressed with respect to NUE: In $\mathrm{UPE}=\mathrm{a} 1+\mathrm{b} 1 \ln \mathrm{NUE} ; \ln \mathrm{UTE}=\mathrm{a} 2+\mathrm{b} 2 \ln \mathrm{NUE} ;(\mathrm{b} 1+\mathrm{b} 2)$ must be $=1$ and thus 
explains the complementary contribution of each component to NUE (Giuliani et al., 2011). Similarly, the contribution of each component to NUEp can be calculated by this means.

\section{Statistical analysis}

An analysis of variance was conducted on the experimental data using SAS 9.3 (SAS Institute Inc., Cary, NC, USA) to study the main effects of mulching methods and their interactions. The least significant difference (LSD) test was performed to calculate the significance of differences between means at $\mathrm{P}<0.05$.

\section{Results}

\section{Yield and water use}

Based on the boundary function concept proposed by French and Scultz (1984) and the improved boundary function establishment method developed by Lin and Liu (2016), we obtained the winter wheat boundary function of yield-ET in the Loess Plateau (Fig. 1). The upper boundary of the yield-ET relationship can be fitted using the function Yield $=14.8$ (ET-42.3), which means that under plastic film mulch in this area, the maximum transpiration efficiency is $14.8 \mathrm{~kg} \mathrm{ha}^{-1} \mathrm{~mm}^{-1}$.

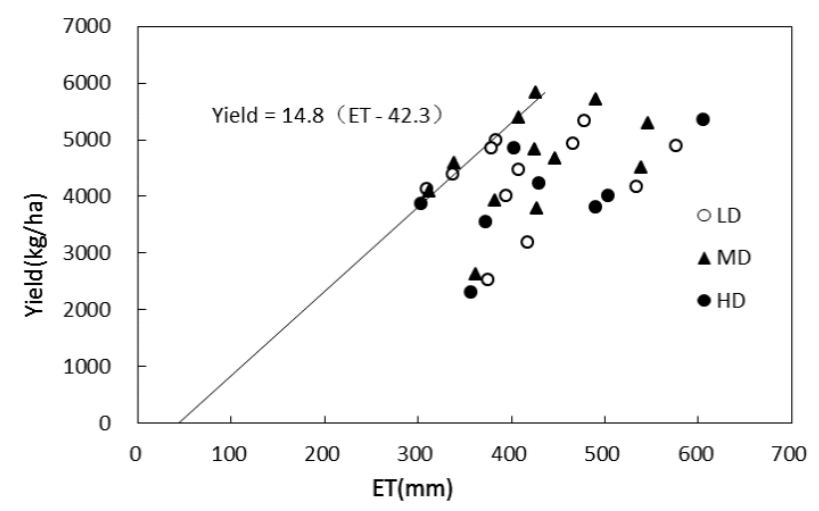

Figure 1. Yield and ET relationship under different seeding rates. The boundary line was generated according to (Lin and Liu, 2016) and shows the maximum yield under different ET

The results show that compared with CK, SS increased the soil water storage by an average of $58 \mathrm{~mm}$ during the 4 years $(\mathrm{p}<0.001)$. The average yield under SS was $4821 \mathrm{~kg} / \mathrm{ha}$, which was $950 \mathrm{~kg}$ higher than the $3877 \mathrm{~kg} / \mathrm{ha}$ of CK (p < 0.001). Higher soil water storage provided more water for crop use during the growth period; hence, the ET for SS was significantly higher than that of CK. The WUEs for SS and CK were 10.6 and $10.2 \mathrm{~kg}$ ha $\mathrm{mm}$, respectively, without a significant difference. The WUEp for SS was significantly higher than that of CK (Table 3).

To evaluate the seeding rate impact on the yield and water use of winter wheat, we calculated the data based on the seeding rate (Table 4). The results showed that the wheat yields were 4324, 4787 and $3998 \mathrm{~kg} / \mathrm{ha}$ for the low-, mid- and high-seeding rate treatments, respectively $(\mathrm{p}<0.05)$. No significant difference was observed for ET among different seeding rates. The difference in WUE and WUEp under different 
seeding rates was much the same as that of yield, i.e., highest at the mid-seeding rate, second in the low-seeding rate and lowest in the high-seeding rate.

Table 3. Yield, water consumption and WUE under different tillage measures

\begin{tabular}{c|c|c|c|c|c}
\hline Tillage & Yield (kg/ha) & $\begin{array}{c}\text { Soil water storage before } \\
\text { sowing }(\mathbf{m m})\end{array}$ & $\begin{array}{c}\mathbf{E T} \\
(\mathbf{m m})\end{array}$ & $\begin{array}{c}\text { WUE } \\
\left(\mathbf{k g ~ h a}^{-1} \mathbf{~ m m}^{-\mathbf{1}}\right)\end{array}$ & $\begin{array}{c}\text { WUEP } \\
\left(\mathbf{k g ~ h a}_{\mathbf{~}} \mathbf{~ m m}^{\mathbf{- 1}}\right)\end{array}$ \\
\hline SS & 4821 & 526 & 461 & 10.6 & 11.3 \\
CK & 3877 & 468 & 391 & 10.2 & 9.1 \\
Prob & $0.041^{* *}$ & $0.045^{* *}$ & $0.045^{* *}$ & 0.064 & $0.041^{* *}$ \\
\hline
\end{tabular}

**Significant difference between SS and CK based on $t$ test at the $\mathrm{p}<0.05$ significance level; ns: no significant difference was observed

Table 4. Yield, water consumption and WUE under different seeding rates. $L, M$, and $H$ represent low-, mid-and high-seeding rates, respectively. Values followed by different letters within the same row are significantly different $(P<0.05)$

\begin{tabular}{c|c|c|c|c}
\hline Seeding rate & $\begin{array}{c}\text { Yield } \\
(\mathbf{k g} / \mathbf{h a})\end{array}$ & $\begin{array}{c}\text { ET } \\
(\mathbf{m m})\end{array}$ & $\begin{array}{c}\text { WUE } \\
\left(\mathbf{k g ~ h a}^{-\mathbf{1}} \mathbf{m m}^{\mathbf{- 1}}\right)\end{array}$ & $\begin{array}{c}\text { WUE } \\
\left(\mathbf{k g ~ h a}_{\mathbf{P}}^{\mathbf{1}} \mathbf{m m}^{\mathbf{- 1}}\right)\end{array}$ \\
\hline $\mathrm{L}$ & $4324 \mathrm{~b}$ & $421 \mathrm{a}$ & $10.5 \mathrm{~b}$ & $10.1 \mathrm{~b}$ \\
$\mathrm{M}$ & $4787 \mathrm{a}$ & $431 \mathrm{a}$ & $11.3 \mathrm{a}$ & $11.1 \mathrm{a}$ \\
$\mathrm{H}$ & $3998 \mathrm{c}$ & $433 \mathrm{a}$ & $9.4 \mathrm{c}$ & $9.4 \mathrm{c}$ \\
$\mathrm{LSD}_{0.05}$ & 301 & 12.5 & 0.7 & 0.7 \\
\hline
\end{tabular}

\section{Nitrogen uptake and translocation}

Under subsoiling, the NUE was $31.31,34.10$ and $30.43 \mathrm{~kg} / \mathrm{ha}$ for the low-, mid- and high-seeding rates (Table 5). Under CK, the NUE decreased to 25.32, 26.51 and $21.91 \mathrm{~kg} / \mathrm{kg}$, respectively. The UTE for SS was significantly higher than that of CK under all seeding rates. However, the situation among different seeding rates was not the same for the NUE. The NUEs were highest under the mid-seeding rate. The UTE was highest at a low-seeding rate under SS and highest at a high-seeding rate under CK. The UPE is a component of both NUE and NUEp, and it was highest at the mid-seeding rate, with values of 1.06 and 1.01 in SS and CK, respectively (Table 5). However, for $\mathrm{CK}$, there was no significant difference among seeding rates. The NUEp tended to be lower under CK than under SS. Under the same tillage method, the mid-seeding rate showed the highest NUEp. The average NHI was approximately 0.82 , and no significant difference was observed between treatments.

\section{Contributions of NUE and NUEp}

Figure 2 shows the calculation process for NUEp under SS and CK. The slope of the regression function is the contribution of each component to NUEp. The contribution of NHI to NUEp was $20.84 \%$, and under CK, it decreased to $12.92 \%$. The contribution of UPE to NUEp was $79.16 \%$, and under CK, it increased to $87.08 \%$. Hence, SS led to a higher contribution of UPE and a lower contribution to NHI.

The contribution of UPE to NUEp was $84.96 \%, 81.12 \%$ and $76.59 \%$ for the high-, mid- and low-seeding rates, respectively (Table 6). The contribution of UPE to NUE was $67.05 \%, 48.95 \%$ and $36.06 \%$ for the high-, mid- and low-seeding rates, 
respectively (Table 7). The contribution of NHI to NUEp was $15.04 \%, 17.87 \%$ and $23.41 \%$ for the high-, mid- and low-seeding rates, respectively. The contribution of UTE to NUE increased as the seeding rate increased, ranking $32.95 \%, 51.05 \%, 63.94 \%$ for the high-, mid- and low-seeding rates, respectively.

Table 5. $N$ use efficiency and its components. $N U E=Y / N f$, NUEp $=N g / N f$, UPE $=N t / N f$, $U T E=Y / N t, N H I=N g / N t . L, M$, and $H$ represent low-, mid- and high-seeding rates, respectively. Values followed by different letters within the same row are significantly different $(P<0.05)$. **Significance at $p<0.05$

\begin{tabular}{|c|c|c|c|c|c|c|}
\hline Tillage & $\begin{array}{c}\text { Seeding } \\
\text { rate }\end{array}$ & $\begin{array}{c}\text { NUE } \\
(\mathrm{kg} / \mathrm{kg})\end{array}$ & $\begin{array}{c}\mathrm{UTE} \\
(\mathrm{kg} / \mathrm{kg})\end{array}$ & $\begin{array}{c}\mathrm{UPE} \\
(\mathrm{kg} / \mathrm{kg})\end{array}$ & $\begin{array}{c}\text { NUEp } \\
(\mathrm{kg} / \mathrm{kg})\end{array}$ & $\begin{array}{c}\mathrm{NHI} \\
(\mathrm{kg} / \mathrm{kg})\end{array}$ \\
\hline \multirow{3}{*}{ SS } & Low & $31.31 \mathrm{~b}$ & $33.50 \mathrm{a}$ & $0.96 \mathrm{~b}$ & $0.80 \mathrm{~b}$ & $0.83 \mathrm{a}$ \\
\hline & Mid & $34.10 \mathrm{a}$ & $32.47 \mathrm{~b}$ & $1.06 \mathrm{a}$ & $0.90 \mathrm{a}$ & $0.84 \mathrm{a}$ \\
\hline & High & $30.43 \mathrm{c}$ & $31.09 \mathrm{c}$ & $0.98 \mathrm{~b}$ & $0.82 \mathrm{~b}$ & $0.84 \mathrm{a}$ \\
\hline \multirow{3}{*}{ CK } & Low & $25.32 \mathrm{e}$ & $26.82 \mathrm{e}$ & $0.95 \mathrm{~b}$ & $0.79 \mathrm{~b}$ & $0.82 \mathrm{ab}$ \\
\hline & Mid & $26.51 \mathrm{~d}$ & $26.36 \mathrm{e}$ & $1.00 \mathrm{~b}$ & $0.83 \mathrm{~b}$ & $0.82 \mathrm{ab}$ \\
\hline & High & $21.91 \mathrm{f}$ & $27.88 \mathrm{~d}$ & $0.78 \mathrm{c}$ & $0.63 \mathrm{c}$ & $0.80 \mathrm{~b}$ \\
\hline \multirow{2}{*}{\multicolumn{2}{|c|}{$\begin{array}{l}\text { ANOVA SS } \\
\text { Tillage }\left(\mathrm{F}_{\mathrm{T}}\right)\end{array}$}} & & & & & \\
\hline & & $296.4 * *$ & $275.6^{* *}$ & $0.18^{* *}$ & $0.12 * *$ & 0.03 \\
\hline \multicolumn{2}{|c|}{ Seeding rate $\left(F_{S}\right)$} & $75.7 * *$ & $87.5^{* *}$ & $0.15 * *$ & $0.10 * *$ & 0.02 \\
\hline \multicolumn{2}{|c|}{$F_{T} \times F_{S}$} & $26.8^{* *}$ & $32.3 * *$ & 0.03 & 0.05 & 0.02 \\
\hline
\end{tabular}

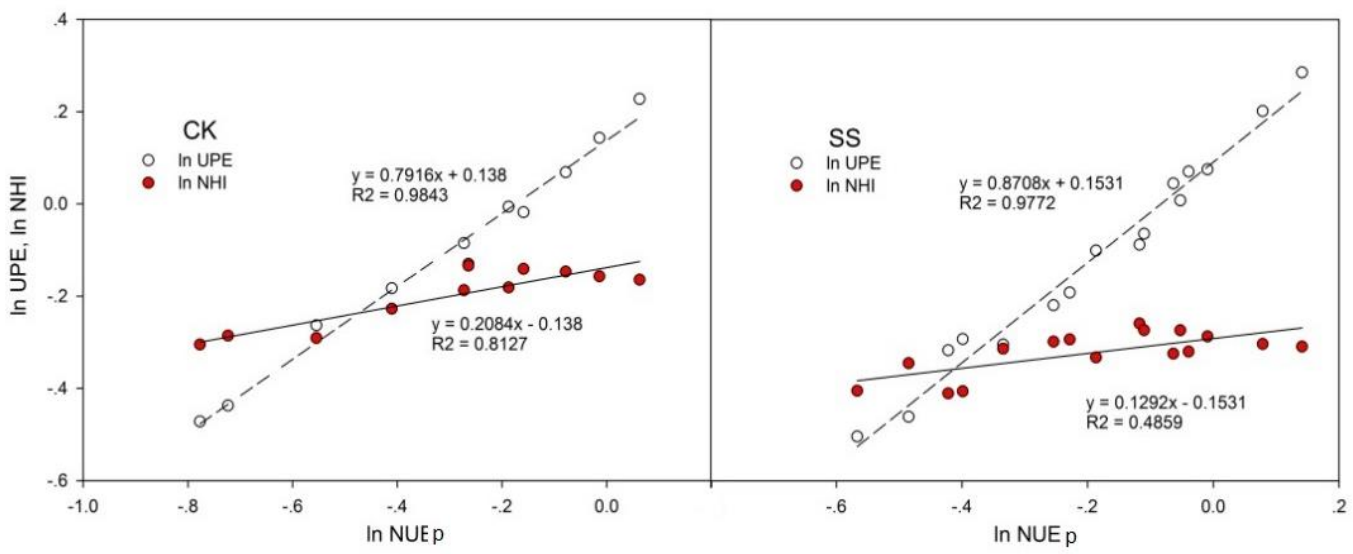

Figure 2. Linear regression of nitrogen uptake efficiency (UPE) and nitrogen utilization for protein (NHIp) components on total nitrogen use efficiency for protein (NUEp) in CK and SS

Table 6. NUEp and its components under different seeding rates. L, $M$, and $H$ represent low-, mid-and high-seeding rates, respectively. Values followed by different letters within the same row are significantly different $(P<0.05)$

\begin{tabular}{c|c|c|c|c|c}
\hline D & NUEp (kg/kg) & UPE & Contribution & NHI & Contribution \\
\hline $\mathrm{L}$ & $0.80 \mathrm{~b}$ & $0.95 \mathrm{~b}$ & $84.96 \%$ & $0.83 \mathrm{a}$ & $15.04 \%$ \\
$\mathrm{M}$ & $0.87 \mathrm{a}$ & $1.04 \mathrm{a}$ & $81.12 \%$ & $0.84 \mathrm{a}$ & $17.87 \%$ \\
$\mathrm{H}$ & $0.74 \mathrm{c}$ & $0.89 \mathrm{c}$ & $76.59 \%$ & $0.82 \mathrm{a}$ & $23.41 \%$ \\
LSD $_{0.05}$ & 0.59 & 0.05 & - & 0.03 & - \\
\hline
\end{tabular}


Table 7. NUE and its components. $L, M$, and $H$ represent the low-, mid-and high-seeding rates, respectively. Values followed by different letters within the same row are significantly different $(P<0.05)$

\begin{tabular}{c|c|c|c|c|c}
\hline D & NUE $(\mathbf{k g} / \mathbf{k g})$ & UPE & Contribution & UTE & Contribution \\
\hline $\mathrm{L}$ & $28.92 \mathrm{~b}$ & $0.95 \mathrm{~b}$ & $67.05 \%$ & $30.83 \mathrm{a}$ & $32.95 \%$ \\
$\mathrm{M}$ & $31.06 \mathrm{a}$ & $1.04 \mathrm{a}$ & $48.95 \%$ & $30.02 \mathrm{~b}$ & $51.05 \%$ \\
$\mathrm{H}$ & $26.78 \mathrm{c}$ & $0.89 \mathrm{c}$ & $36.06 \%$ & $29.72 \mathrm{~b}$ & $63.94 \%$ \\
LSD $_{0.05}$ & 1.58 & 0.05 & - & 0.55 & - \\
\hline
\end{tabular}

\section{Discussion}

\section{Seeding rate and wheat water yield potential}

The boundary analysis results show that most of the dots close to the boundary line were the mid-seeding rate treatment and low-seeding rate treatment (Fig. 1). This result means that a high seeding rate is not appropriate for making full use of water resources in this region. The intercept of the boundary line represents the minimum soil evaporation in this area (Sadras and Angus, 2006). In this research, the intercept is $42.3 \mathrm{~mm}$, which was lower than the value of $60 \mathrm{~mm}$ reported by Zhang (2013). The main reason is that plastic film was used in this research, and plastic is effective in reducing soil evaporation (Li et al., 2005).

\section{Subsoiling influence on wheat yield and WUE}

In SS, the ET and yield increased significantly, but no significant difference was observed in the WUE (Table 3). However, this does not mean that SS had no impact on water resource use in dryland wheat. SS increased precipitation infiltration into the soil in the summer period; hence, more water was stored in the soil before sowing (Williams et al., 2006), which means that more water was available for crop growth and soil evaporation. Hence, the ET was increased (Lin et al., 2016). Because ET and yield were increased in a similar ratio under SS in this research, the WUE remained the same. However, in dryland farming, a high WUE should be considered, but it makes no sense if the high WUE is based on a low yield and low ET. The effective use of water should be the goal to improve the crop yield in dryland areas (Blum, 2009). In the Loess Plateau, without irrigation and groundwater supplementation, soil water is supplied by precipitation; hence, precipitation is the only source of water for crop growth (Lin et al., 2019). However, more water was used under SS because more water was within reach for the crop. We further calculated the WUE of precipitation (WUEp) in a hydrological year (fallow period + growth period) and found that the WUEp under SS increased significantly (Table 3). SS significantly used the limited precipitation available in the dryland farming area.

Fang (2010) found that ET increased as the seeding rate increased. In this study, although ET showed an increasing trend as the seeding rate increased, no significant difference was found in the ET values among the different seeding rate treatments. This difference may be due to differences in the environment at the experimental sites. Compared with Fang's research, precipitation was lower in this research. Under a highseeding rate, the large population calls for more water for transpiration use, but the shading effect of higher shoot coverage may reduce the soil evaporation; under a lowseeding rate, less water is used by transpiration, but more soil is exposed to the air 
directly, and hence more water is evaporated (Li et al., 2013). Iqbal et al. (2012) found that the mid-seeding rate helped obtain a high yield. In this research, we found a similar result. The wheat yield was highest in the mid-seeding rate treatment and lowest in the high-seeding rate treatment. Thus, a suitable seeding rate is important for achieving a high yield. This may be the reason why similar ET values were found among the different seeding rates in this study.

\section{$N$ uptake and utilization}

SS increased the soil water content and improved the soil air condition, which increased the availability of nutrients and eased the uptake of nutrients by roots (Zhu et al., 2018); hence, UPE was higher in SS than in CK (Table 1). The higher UPE further led to a higher NUEp for SS, although there was no significant difference in the NHI among treatments. Contribution analysis showed that the contribution to NUEp was CK $<$ SS for UPE and CK > SS for NHI. Giuliani et al. (2011) found that the contribution of UPE to NUEp was lower in dry years than in wet years. In this research, SS improved the soil water condition before sowing, which resembled a wetter condition compared with that in CK. A higher contribution of UPE means that the increased NUEp under SS was mainly due to the increased UPE.

NUE and NUEp were highest for the mid-seeding rate treatment. This result means that a moderate planting density helps make full use of nitrogen (Arduini et al., 2006). In agreement with several previous studies (Van Sanford and Mackown, 1986; Giuliani et al., 2011), the contribution of UPE to NUEp was higher than that of NHI under all seeding rates (Table 6). The contribution of UPE to NUEp decreased as the seeding rate increased, and the contribution of NHI increased as the seeding rate increased. For NUE, the contribution of UPE was higher than that of UTE at low-seeding rates, similar at mid-seeding rates and lower at high-seeding rates.

In this study, because the available soil $\mathrm{N}$ before seeding was not measured, nitrogen from fertilizer (Nf) was used instead of the nitrogen supply (Ns, expressed as Nf plus available soil nitrogen). This represents a limitation of this study. However, fertilizer $\mathrm{N}$ is an important $\mathrm{N}$ source for wheat growth; hence, the results still make sense for wheat production in dryland areas.

\section{Conclusions}

In order to make full use of the limited water resources and improve nitrogen fertilizer use efficiency (NUE) in the dryland farming area, the effects of seeding rate and tillage on water use and nitrogen use were analyzed. We found that under plastic film mulch, soil evaporation is effectively reduced for the winter wheat in the Loess Plateau. Subsoiling during the summer fallow period increased soil water retention and improved wheat yield and WUEp. It also increased nitrogen uptake and NUEp. The mid-seeding rate (approximately $90 \mathrm{~kg} / \mathrm{ha}$ ) increased the wheat yield and WUE and increased the contribution of NHI to NUEp but decreased the contribution of UPE to NUEp, which led to the highest NUEp. The results of this study focused on the overall use of $\mathrm{N}$ fertilizer absorption and utilization, to make a full understanding about how seeding rate and subsoiling influence $\mathrm{N}$ utilization process, $\mathrm{N}$ concentration in plant and enzymatic activity related to $\mathrm{N}$ enzymatic activity should be measured in future study. 
Acknowledgments. We gratefully acknowledge the anonymous reviewers for their constructive comments. This work was funded by Science \& Technology Innovation Foundation of Shanxi Agricultural University (2017YJ24), Outstanding Doctor Funding Award of Shanxi Province (SXYBKY201749). This work was also supported by the earmarked fund for China Agriculture Research System (CARS-03-01-24), the National Natural Science Foundation of China (31771727).

\section{REFERENCES}

[1] Arduini, I., Masoni, A., Ercoli, L., Mariotti, M. (2006): Grain yield, and dry matter and nitrogen accumulation and remobilization in durum wheat as affected by variety and seeding rate. - European Journal of Agronomy 25(4): 309-318.

[2] Basso, B., Cammarano, D., Troccoli, A., Chen, D., Ritchie, J. T. (2010): Long-term wheat response to nitrogen in a rainfed Mediterranean environment: field data and simulation analysis. - European Journal of Agronomy 33(2): 132-138.

[3] Bhatt, R., Khera, K. (2006): Effect of tillage and mode of straw mulch application on soil erosion in the submontaneous tract of Punjab, India. - Soil and Tillage Research 88(1-2): 107-115.

[4] Bhatta, M., Eskridge, K. M., Rose, D. J., Santra, D. K., Baenziger, P. S., Regassa, T. (2017): Seeding rate, genotype, and topdressed nitrogen effects on yield and agronomic characteristics of winter wheat. - Crop Science 57(2): 951-963.

[5] Blum, A. (2009): Effective use of water (EUW) and not water-use efficiency (WUE) is the target of crop yield improvement under drought stress. - Field Crops Research 112(23): $119-123$.

[6] Delogu, G., Cattivelli, L., Pecchioni, N., De Falcis, D., Maggiore, T., Stanca, A. (1998): Uptake and agronomic efficiency of nitrogen in winter barley and winter wheat. European Journal of Agronomy 9(1): 11-20.

[7] Fang, Y., Xu, B.-C., Turner N. C., Li, F.-M. (2010): Grain yield, dry matter accumulation and remobilization, and root respiration in winter wheat as affected by seeding rate and root pruning. - European Journal of Agronomy 33(4): 257-266.

[8] French, R., Schultz, J. (1984) Water use efficiency of wheat in a Mediterranean-type environment. I. The relation between yield, water use and climate. - Aust. J. Agr. Res. 35: 743-764.

[9] Giuliani, M. M., Giuzio, L., Caro, A. D., Flagella, Z. (2011): Relationships between nitrogen utilization and grain technological quality in durum wheat: I. Nitrogen translocation and nitrogen use efficiency for protein. - Agronomy Journal 103(5): 14871494.

[10] Gómez, J., Giráldez, J., Pastor, M., Fereres, E. (1999): Effects of tillage method on soil physical properties, infiltration and yield in an olive orchard. - Soil and Tillage Research 52(3-4): 167-175.

[11] Guntiñas, M. E., Leirós, M., Trasar-Cepeda, C., Gil-Sotres, F. (2012): Effects of moisture and temperature on net soil nitrogen mineralization: a laboratory study. - European Journal of Soil Biology 48: 73-80.

[12] Halvorson, A. D., Nielsen, D. C., Reule, C. A. (2004) Nitrogen fertilization and rotation effects on no-till dryland wheat production. - Agron J 96: 1196-1201.

[13] Han, X., Liu, W., Lin, W. (2015): Spatiotemporal analysis of potential evapotranspiration in the Changwu tableland from 1957 to 2012. - Meteorological Applications 22(3): 586591.

[14] Iqbal, J., Hayat, K., Hussain, S., Ali, A., Bakhsh, M. A. A. H. A. (2012): Effect of seeding rates and nitrogen levels on yield and yield components of wheat (Triticum aestivum, L.). - Pakistan Journal of Nutrition 11(7): 531. 
[15] Kang, S., Zhang, L., Liang, Y., Hu, X., Cai, H., Gu, B. (2002): Effects of limited irrigation on yield and water use efficiency of winter wheat in the Loess Plateau of China. - Agricultural Water Management 55(3): 203-216.

[16] Kühling, I., Redozubov, D., Broll, G., Trautz, D. (2017): Impact of tillage, seeding rate and seeding depth on soil moisture and dryland spring wheat yield in Western Siberia. Soil and Tillage Research 170: 43-52.

[17] Li, F., Wang, J., Xu, J. (2005): Plastic film mulch effect on spring wheat in a semiarid region. - J. Sustain. Agr. 25(4): 5-17.

[18] Li, S., Wang, Z., Li, S., Gao, Y., Tian, X. (2013): Effect of plastic sheet mulch, wheat straw mulch, and maize growth on water loss by evaporation in dryland areas of China. Agricultural Water Management 116: 39-49.

[19] Liao, Y., Han, S., Wen, X. (2002): Soil water content and crop yield effects of mechanized conservative tillage-cultivation system for dryland winter wheat in the Loess Tableland. - Transactions of the Chinese Society of Agricultural Engineering 2002(4).

[20] Lin, W., Liu, W. (2016): Establishment and application of spring maize yield to evapotranspiration boundary function in the Loess Plateau of China. - Agricultural Water Management. 178: 345-349.

[21] Lin, W., Liu, W., Xue, Q. (2016): Spring maize yield, soil water use and water use efficiency under plastic film and straw mulches in the Loess Plateau. - Scientific Reports 6: 38995.

[22] Lin, W., Liu, W., Zhou, S., Liu, C. (2019): Influence of plastic film mulch on maize water use efficiency in the Loess Plateau of China. - Agricultural Water Management 224: 105710.

[23] Ma, D., Chen, L., Qu, H., Wang, Y., Misselbrook, T., Jiang, R. (2018): Impacts of plastic film mulching on crop yields, soil water, nitrate, and organic carbon in Northwestern China: a meta-analysis. - Agricultural Water Management 202: 166-173.

[24] Moll, R. H., Kamprath, E. J., Jackson, W. A. (1982): Analysis and interpretation of factors which contribute to efficiency of nitrogen utilization. - Agronomy Journal 74(3): 562-564.

[25] Nielsen, D. C., Vigil, M. F. (2010): Precipitation storage efficiency during fallow in wheat-fallow systems. - Agronomy Journal 102(2): 537.

[26] Sadras, V. O., Angus, J. F. (2006): Benchmarking water-use efficiency of rainfed wheat in dry environments. - Australian Journal of Agricultural Research 57(8): 847-856.

[27] Sadras, V. O., Lawson, C. (2013): Nitrogen and water-use efficiency of Australian wheat varieties released between 1958 and 2007. - European Journal of Agronomy 46(2): 3441.

[28] Van Sanford, D. A., Mackown, C. T. (1986): Variation in nitrogen use efficiency among soft red winter wheat genotypes. - Theoretical \& Applied Genetics (Theoretische und angewandte Genetik) 72(2): 158.

[29] Wang, J., Liu, W., Dang, T. (2011): Responses of soil water balance and precipitation storage efficiency to increased fertilizer application in winter wheat. - Plant and soil 347(1-2): 41-51.

[30] Williams, J. D., Wuest, S. B., Schillinger, W. F., Gollany, H. T. (2006): Rotary subsoiling newly planted winter wheat fields to improve infiltration in frozen soil. - Soil and Tillage Research 86(2): 141-151.

[31] Zhang, S., Sadras, V., Chen, X., Zhang, F. (2013): Water use efficiency of dryland wheat in the Loess Plateau in response to soil and crop management. - Field Crops Research 151: 9-18.

[32] Zhu, Q., Castellano, M. J., Yang, G. (2018): Coupling soil water processes and nitrogen cycle across spatial scales: potentials, bottlenecks and solutions. - Earth-Science Reviews $4(2): 35-40$. 
[33] Zhu, Z., Chen, D. (2002): Nitrogen fertilizer use in China. Contributions to food production, impacts on the environment and best management strategies. - Nutrient Cycling in Agroecosystems 63(2-3): 117-127. 